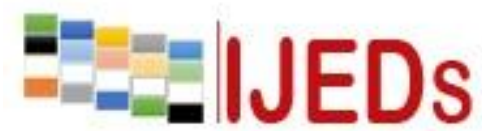

http://ijeds.ppj.unp.ac.id/index.php/IJEDS

\title{
THE IMPACT OF COGNITIVE CONFLICT BASED LEARNING TOOLS ON STUDENTS`MATHEMATICAL PROBLEM SOLVING ABILITY
}

\author{
*Randi Putra ${ }^{1}$, Ahmad Fauzan ${ }^{2}$, Mhmd Habibi $^{3}$ \\ ${ }^{1}$ Graduate Students Universitas Negeri Padang, Indonesia \\ ${ }^{2}$ Lecturer Mathematics Educations, Universitas Negeri Padang, Indonesia \\ ${ }^{3}$ Lecturer Mathematics Esducations, IAIN Kerinci, Indonesia. \\ Email: randiputra68@gmail.com
}

*Corresponding Author, Received: November 12, 2019, Revised: December 10, 2019, Accepted: December 21, 2019

\begin{abstract}
This study aims to produce effectiveness from the development of learning tools through the concept of algebraic forms using Cognitive Conflict-Based Learning $(\mathrm{PbKK})$ models for mathematical problem-solving abilities that are implemented in the Learning Implementation Plan (RPP) and Student Worksheet (LKPD) that are valid and practical. The method used is the Plomp design research model which consists of three phases, namely the preliminary research phase, the development phase (development or prototyping phase) and the assessment phase. The subjects of the study were the seventh grade students of junior high school. Data collection techniques used was posttest tests from two classes, namely the experimental class and the control class. Data analysis techniques are using the Independent-Sample $\mathrm{T}$ Test. The analysis shows that $\mathrm{p}$-value $=0.034<0.05$ means that there are significant differences between the two classes. So, the development of Cognitive Conflict-based learning tools has a positive impact on students' mathematical problem solving abilities in algebraic form material.
\end{abstract}

Keywords : Learning tools, Cognitive Conflict, Mathematical Problem Solving

\section{INTRODUCTION}

The form of algebra is a branch of mathematics that in problem solving uses symbols in the form of letters that represent unknown numbers or values. This form of algebra is not only used in mathematics but also used in other fields of science such as natural sciences, computer science, economics, business, technology, finance, and others [1-3]. The form of algebra is one of the mathematical materials that is less liked and considered difficult by students. From the results of research conducted by 


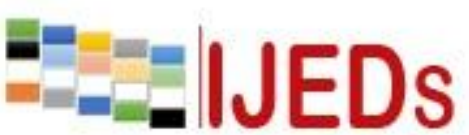

http://ijeds.ppj.unp.ac.id/index.php/IJEDS
International Journal of Educational Dynamics

Vol. 2 No. 1 (pp. 209-218) Desember 2019

p_ISSN 2655-4852

e_ISSN 2655-5093

Hasibuan, et al [4-8] shows that students have difficulty in the concept of algebraic forms, initial abilities, learning models used by teachers in teaching and difficult to overcome misunderstandings caused by misconceptions that occur in students regarding the concepts the concept of algebraic form. Nurhamsiah's research [9] found problems that students still had difficulty identifying coefficients, variables, similar tribes, difficulty carrying out the addition and subtraction of positive and negative terms, difficulty in determining the results of addition and subtraction of different types of operations, difficulty in determining the results of subtracting one by syllable, the difficulty of doing the distributive properties of multiplication in addition. In this case it is clear that the form of the alajbar is a difficult material for students.

One of the factors that influence the difficulties experienced by students is the learning process and learning resources that have not been able to solidify existing concepts in students. Wayan, et al [10] stated that in order to solidify concepts in students there needs to be learning resources in this case the Learning Implementation Plan (RPP) and Student Worksheets (LKPD) based on an appropriate learning model that is to strengthen and enhance students' understanding of concepts. But the reality on the ground shows that learning resources (RPP, LKPD) are rarely found based on learning models that are able to strengthen and enhance students' understanding of concepts. If we look at learning activities on learning resources that are commonly used today are still too monotonous, that is, starting from giving a definition and continuing on decreasing formulas, sample problems and problem solving. There are no activities that involve students directly to find concepts, solve problems either in detail or simply. As a result of the activity that is watched is the lack of active students to construct understanding of concepts and not knowing the misconceptions (misconceptions) students had before. In addition, learning resources that contain monotonous activities encourage teachers to teach mathematics mechanically and algorithmically [11-15].

One of the basic abilities students must master is the ability to solve mathematical problems. Through the ability to solve mathematical problems students are expected to be able to use the rules systematically and connect various rules that have previously been known to solve the problem at hand. But the reality of the current learning process students in general are still confused to understand the problems so 


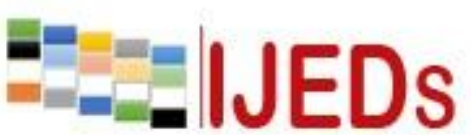

http://ijeds.ppj.unp.ac.id/index.php/IJEDS
International Journal of Educational Dynamics

Vol. 2 No. 1 (pp. 209-218) Desember 2019

p_ISSN 2655-4852

e_ISSN 2655-5093

students find it difficult to determine what strategies or rules are appropriate to use to solve the problems faced so that in the end the students' mathematical problem solving abilities become low. This is evident from the results of the literacy analysis conducted by Fauzan and Tasman [16] in the Province of West Sumatra with the conclusion that the mathematical abilities of junior high school / MTs students still tend to be low. One of the mathematical abilities discussed is the ability to solve mathematical problems, where the percentage of $40.957 \%$ of students get a low score, $34,574 \%$ get a moderate score, and $24.468 \%$ get a high score.

To improve the quality of mathematics learning, teachers need to develop learning tools in the form of lesson plans (RPP) and student worksheets (LKPD) which are based on a learning model that is able to increase understanding and stabilization of student concepts and student-centered learning activities.

One learning model that can improve students 'understanding and stabilization of concepts and improve students' mathematical problem solving abilities is cognitive conflict based learning models. Cognitive Conflict-Based Learning Model is a learning model that enhances students' understanding of concepts by contrasting false concepts with students with actual scientific concepts, so students will realize their mistakes and change or complement the concepts they understand, also very helpful for solving problems that might be encountered in the future coming [17-19]. According to Osborne [20] Cognitive conflict models have a general pattern, namely: exposing alternative framework (expressing initial conceptions), creating conceptual cognitive (creating conceptual conflicts), and encouraging cognitive accommodation (seeking cognitive accommodation). There are several expert opinions regarding the stages of cognitive conflict based learning models, one of which is used in this study is the stages proposed by Mufit [21] namely there are four stages in cognitive conflict based learning models. The first stage is the activation of preconceptions and misconceptions, the second is the presentation of cognitive conflict, the third is the discovery of concepts and equations, and the last is the reflection stage. If we look at the stages of learning that exist in the cognitive conflict based learning model, it is mostly done by students. 


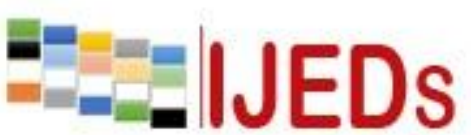

http://ijeds.ppj.unp.ac.id/index.php/IJEDS
International Journal of Educational Dynamics

Vol. 2 No. 1 (pp. 209-218) Desember 2019

p_ISSN 2655-4852

e_ISSN 2655-5093

The purpose of this study is to examine the effectiveness of cognitive conflictbased learning tools on algebraic form material on students' mathematical problem solving abilities.

\section{METHOD}

This type of research is development research. The learning device development model that will be used is the Plomp model [22]. This model has three stages, namely the preliminary investigation, the prototyping stage, and the assessment phase.

The preliminary investigation is carried out needs analysis, curriculum analysis, analysis of student characteristics, and concept analysis. The second stage or the stage of making Prototype is carried out formative evaluation, design and evaluation activities. The steps of formative evaluation start from own evaluation, expert review, one-on-one evaluation, small group evaluation and field test. The instruments used in this study include a list of interview questions, validation sheets, observation sheets, questionnaires. Before being used, each instrument was validated by expert experts and carried out practicality tests to see the ease of use of the learning tools developed.

The third stage is the assessment phase (assessment phase). At the assessment stage the students' mathematical communication skills were tested to determine the effectiveness of cognitive conflict-based learning tools. Data collection techniques used was posttest tests from two classes, namely the experimental class and the control class. The subjects of this study were students of class VII junior high school 27 Kerinci. The effectiveness of cognitive conflict based learning tools is defined as an increase in students' problem solving abilities.

\section{RESULTS AND DISCUSSION}

The assessment phase is carried out to determine the effectiveness of the learning tools through the RPP and LKPD. The potential impact of learning tools is measured through the posttest of the two classes for comparison. For the experimental class using cognitive conflict based learning tools and the control class using ordinary learning. This aim is to see the development of students' mathematical problem solving abilities in different classes of algebraic form material. Furthermore, the value is processed using descriptive statistics; the results can be seen in Table 1. 
Table 1. Descriptive Statistics of Experimental Classes and Control Classes

\begin{tabular}{|c|c|c|c|c|}
\hline Class & $\mathrm{N}$ & Mean & Std. Deviation & Std. Error Mean \\
\hline Eksperimen & 15 & 74.8667 & 12.19992 & 3.15001 \\
\hline Control & 15 & 65.2000 & 11.61403 & 2.99873 \\
\hline
\end{tabular}

The results of the descriptive statistical analysis in Table 1 show that the average posttest results of the experimental class are higher than the control class. The average difference in the posttest results of the experimental class and the control class is 9.66. This shows that the results of the mathematical problem solving ability of experimental class students are better in the control class.

Based on the normality test using the Kolmogorov Smirnov test, the significance value obtained for the experimental class and the control class is 0.805 or> 0.05 , so that means the data is normally distributed. Both samples have normal distribution; the next step is to test the variance homogeneity.

This homogeneity test uses the Independent Sample $\mathrm{T}$ test. Obtained the significance value of Leven's Test for Equality of Variance is for the variable mathematical problem-solving ability of 0.895 . Because the significance value $>0.05$, it can be said that the data variance of students' mathematical problem-solving abilities of the two groups is the same (homogeneous). After obtaining that the results of the analysis of both homogeneous variances t-test was performed. The data shows that the significance is $0.034<0.05$, which means that there are significant differences between the two experimental and control classes when the test is done on the students' mathematical problem solving abilities. The following is a description and analysis of student answers in accordance with indicators of students' mathematical solving abilities in the experimental class and the control class.

Indicator 1: Understand the problem by identifying the elements that are known, asked for and the adequacy of the elements needed. The results of student answers can be seen in the following picture.

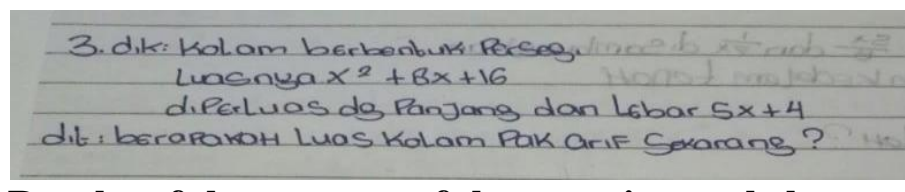

Figure 1. Results of the answers of the experimental class students 


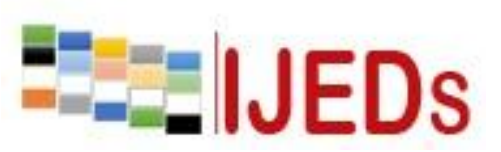

http://ijeds.ppj.unp.ac.id/index.php/IJEDS

$$
\begin{aligned}
& \text { Jaaka. } \\
& x^{2}+8 x+16,5 x+4
\end{aligned}
$$

Figure 2. The results of the control class students' answers

For the first indicator on this problem the students are asked to work on is identifying the elements of Mr. Arif's pool that are known such as the shape of the pool, initial area, area added and what is asked about the problem is the area of Mr. Arif's pond after it was expanded. The results of the answers in the experimental class indicate that students have been able to identify all the elements needed in full for the initial steps of solving the problem and are able to identify what is asked in the questions posed; this means students in the experimental class have been able to understand the problems given. In contrast to the experimental class, students in the control class have also identified elements that are known but are still incomplete which will cause students to be difficult to solve the problems encountered.

Indicator 2: Develop a problem-solving plan.

The results of student answers can be seen in the following picture.

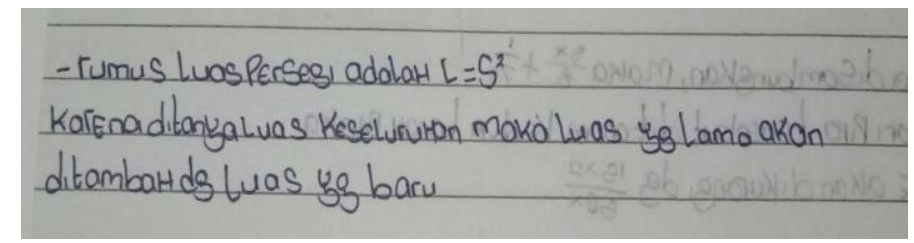

Figure 3. Results of the answers of the experimental class students

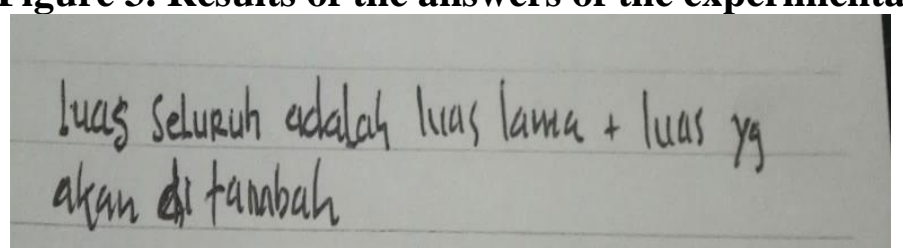

Figure 4. Results of control class students' answers

For the second indicator in this problem the students are asked to do is to develop a problem-solving plan such as the formulas used and to link the information with the element in question. Based on the answers of students in the experimental class, students have developed a complete problem-solving plan such as writing the square area formula because what is known in the new area is only the length of the side, not the area, so the square area formula is needed to determine the area of the added square and students have been able to connect the information existing with the element in question. Unlike the case with the answers of students in the control class, 


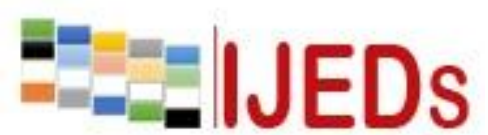

http://ijeds.ppj.unp.ac.id/index.php/IJEDS

the answers of students in the control class for this second indicator only write the relationship between the existing information with the elements asked without writing the formula needed to solve the problem, this will be fatal for students because it will lead students to wrong completion steps.

Indicator 3: Implement a problem solving plan.

The results of student answers can be seen in the following picture.

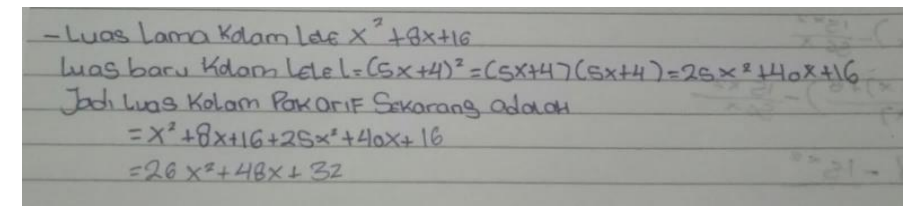

Figure 5. Results of students' answers to the experimental class

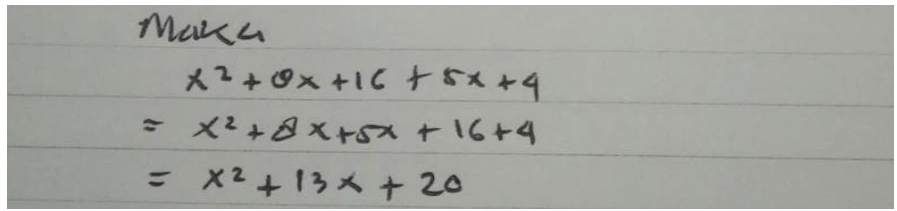

Figure 6. Results of control class students' answers

For the third indicator in this problem the students are asked to do is to carry out the problem plan that was prepared in the previous indicator. In the experimental class students it was seen that the answer given was appropriate in accordance with the questions given in the problem, namely writing the old area of Pak Arif's catfish pool and for the area added because it was known that the length of the sides was to obtain the area added by the student multiplying side by side in accordance with rectangular area formula. Then the old area is added to the new area. The answers of students in the experimental class are very different from the answers of students in the control class. In the control class, students simply add the old area with the length of the new wide side and obviously students will get the wrong answer.

Indicator 4: Re-examine the results obtained.

The results of student answers can be seen in the following picture.

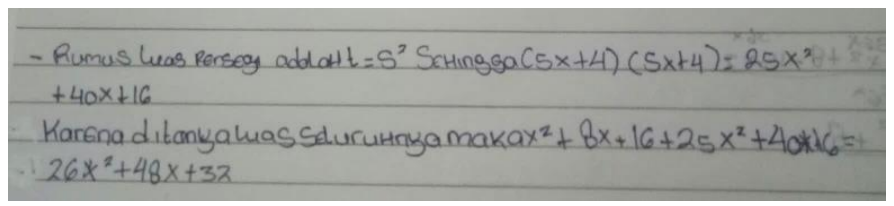

Figure 7. Results of experimental class students' answers 


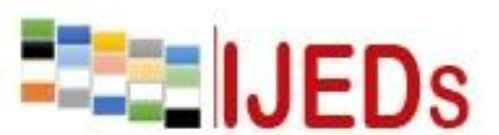

http://ijeds.ppj.unp.ac.id/index.php/IJEDS

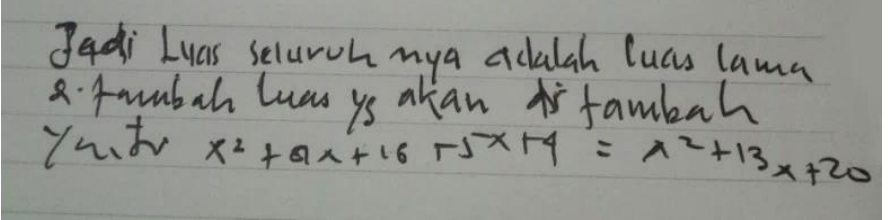

Figure 8. Results of control class students' answers

For the fourth indicator in this problem the students are asked to work on is to double check the answers that are given in accordance with the questions given. Based on the students' answers in the experimental class, it is clear that students have checked the answers exactly according to the questions given. Unlike the case with the answers of students in the control class, students actually have been able to re-check the answers they wrote but because the answers given are wrong then the re-examination carried out does not mean anything.

Based on the description and analysis of the results of students 'answers from the two classes, the experimental class tends to be better at seeing the development of students' mathematical problem solving abilities. The results of the students' answers above only represent some students. Therefore, the development of cognitive conflictbased learning tools conducted in the experimental class can improve students' mathematical problem solving abilities. So based on the three results of this effectiveness test analysis, it can be concluded that cognitive conflict-based learning tools have a positive impact on students' mathematical problem solving abilities on the topic of algebraic forms.

\section{CONCLUSION}

Based on the data obtained from the results of the posttest conducted in two groups, namely the experimental class as a class using cognitive conflict-based learning tools and the control class with conventional treatment, it can be concluded that the development of cognitive conflict-based learning devices has a positive impact on students' mathematical communication abilities.

\section{REFERENCES}

Atmadja dan Joshua, 2015, Penerapan aljabar lanjar pada grafis komputer. Program Studi Teknik Informatika Sekolah Teknik Elektro dan Informatika Institut Teknologi Bandung, Jl. Ganesha 10 Bandung 40132, Indonesia. 


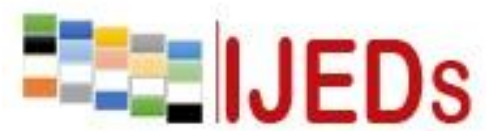

http://ijeds.ppj.unp.ac.id/index.php/IJEDS
International Journal of Educational Dynamics

Vol. 2 No. 1 (pp. 209-218) Desember 2019

p_ISSN 2655-4852

e_ISSN 2655-5093

Zahid Z dan Sujadi I 2017, Pembentukan Konsep Faktorisasi Aljabar Siswa Berkemampuan Tinggi. p-ISSN: 2086-2334; e-ISSN: 2442-4218. Kreano: jurnal matematika kreatif-inovatif. Kreano 8 (1) (2017): 94-100, juni 2017. Universitas Negeri Semarang, Jawa Tengah, Indonesia.

Mulungye M M, O'Connor M, \& Ndethiu, S 2016, Sources of student errors and misconceptions in algebra and effectiveness of classroom practice remediation in Machakos County-- Kenya. Journal of Education and Practice, 7(10), 3133.

Hasibuan I 2015, Hasil belajar siswa pada materi bentuk aljabar di kelas 7 SMP Negeri 1 Banda Aceh. ISSN: 2302-5158. Jurnal Peluang, Volume 4, Nomor 1, Oktober 2015. Universitas Syiah Kuala Aceh.

Sugiarti L 2016, Kesulitan Siswa Dalam Menyelesaikan Soal Operasi Bentuk Aljabar. ISBN: 978-602-6258-07-6. Prosiding Seminar Nasional Etnomatnesia. Pendidikan Matematika Universitas Negeri Yogyakarta.

Diana R F, Irawan E B dan Susiswo, 2017, Proses Koneksi Matematis Siswa Bergaya Kognitif Reflektif Dalam Menyelesaikan Masalah Aljabar Berdasarkan Taksonomi Solo. ISSN: 2549 - 8584. Jurnal Kajian Pembelajaran Matematika Volume 1 Nomor 1, April 2017. Universitas Negeri Malang.

Utami R, 2017, Analisis Miskonsepsi Siswa Dan Cara Mengatasinya Pada Materi Bentuk Aljabar Kelas 7-C Smp Negeri 13 Malang, ISSN: 2442-4668. Jurnal Pendidikan Matematika Volume 3, Nomor 1, Februari 2017, Halaman 37-44. Universitas Islam Malang.

Wahid, Hartoyo A, Mirza A, 2015, Miskonsepsi Siswa Pada Materi Operasi Pada Bentuk Aljabar Kelas Vii Smp Haebat Islam. Jurnal Pendidikan dan Pembelajaran Khatulistiwa Vol. 4 No. 1. Program Studi Pendidikan Matematika FKIP Untan, Pontianak.

Nurhamsiah, 2016, Analisis Kesulitan Siswa Dalam Mempelajari Bentuk Aljabar Berkaitan Dengan Konsep dan Prinsip di SMP. Jurnal Pendidikan dan Pembelajaran Khatulistiwa Vol. 5 No. 2. Program Studi Pendidikan Matematika FKIP Untan, Pontianak.

Wayan, dkk (2013). Pengaruh Strategi Pembelajaran Konflik Kognitif Terhadap Penurunan Miskonsepsi Fisika Ditinjau Dari Gaya Kognitif Siswa Kelas X Di Sma Negeri 1 Bebandem. E-Journal Program Pascasarjana Universitas Pendidikan Ganesha Program Studi Administrasi Pendidikan (Volume 4 Tahun 2013).

Subagja A A, 2013, Mulyati T, 2016, "Pembelajaran Model Treffinger untuk Meningkatkan Pemahaman dan Koneksi Matematis Siswa". Program Studi Pendidikan Matematika Pascasarjana Universitas Pendidikan Indonesia.

Fauzan A, Plomp T and Gravemeijer K, 2013, Educational Design Research Part B: an Introduction ed T Plomp and N Nieveen (Enschede, SLO) p 159-178.

Fauzan A, Armiati A and Ceria C, 2018, A Learning Trajectory for Teaching Social Aritmhetic using RME Approach. IOP Conf. Series: Materials Science and Engineering 335 (2018) 012121.

Gee E, Fauzan A and Atmazaki A, 2018, Designing Learning Trajectory fo Teaching Sequence and Series using RME Approach to Improve Student, problem 
http://ijeds.ppj.unp.ac.id/index.php/IJEDS

Solving Abilities. IOP Conf. Series: Journal of Physics: Conf. Series 1088 (2018) 012096.

Fauzan A, Musdi E and Afriadi J, 2018, Developing Learning Trajectory fo Teaching Statistics at junior high school using RME Approach. IOP Conf. Series: Journal of Physics: Conf. Series 1088 (2018) 012040.

Fauzan dan Tasman, 2012, Laporan Penelitian: Analisis Literasi Matematis Siswa SMP di Sumbar. Padang: Lembaga Penelitian UNP.

Swan M, Wake G and Joubert M, 2005, Developing Conceptual understanding through Cognitive Conflict and Discussion in Mathematics and Science Education. Centre for Research in Mathematics Education University of Nottingham.

Fadlan A, 2011, "Model Pembelajaran Konflik Kognitif Untuk Mengatasi Miskonsepsi Pada Mahasiswa Tadris Fisika Program Kualifikasi S.1 Guru Madrasah". Phenomenom: Jurnal Pendidikan Matematika Dan Ilmu Pengetahuan Alam, November 2011, Vol.2, No.1, Hal.1 - 21 ISSN(P): 2527-3744; ISSN(E):25416499.

Baser M, 2006, Fostering conceptual change by cognitive conflict based instruction on student understanding of heat and temperature concepts. Eurasia Journal of Mathematics,Science and Technology Education. 2(2). 96-114. Retrieved from http://www.ejmste.com/ 022006/ d6.pdf.

Osborne. 1993. "Beyond Constructivism". Proceedings of the Third International Seminar on Misconceptions and Educational Strategies in Science and Mathematics, Misconceptions Trust: Ithaca, NY (1993).

Mufit F, Festiyed F, Fauzan A and Lufri L, 2018, Impact of Learning Model Based on Cognitive Conflict toward Student`s Conceptual understanding. IOP Conf. Series: Materials Science and Engineering 335 (2018) 012072.

Plomp T and Nieveen N 2013, "Educational Design Research". Enshede: Netherlands Institute For Curriculum Development (SLO). 